\title{
IS THE GOODWILL RECOGNISED IN A BUSINESS COMBINATION AN INDICATOR OF THE FUTURE PROFITABILITY OF THE COMBINED COMPANY?
}

\author{
Magdalena Janowicz \\ University of Szczecin, Szczecin, Poland \\ Institute of Economics and Finance, Department of Accounting \\ e-mail: magdalena.janowicz@usz.edu.pl \\ ORCID: 0000-0001-5474-197X
}

\section{Piotr Luty}

Wroclaw University of Economics and Business, Wroclaw, Poland

Department of Accounting, Reporting and Financial Analysis

e-mail: piotr.luty@ue.wroc.pl

ORCID: 0000-0003-0955-7000

\section{(C) 2019 Magdalena Janowicz, Piotr Luty}

This is an open access article distributed under the Creative Commons Attribution-NonCommercial-NoDerivs license (http://creativecommons.org/licenses/by-nc-nd/3.0/)

DOI: 10.15611/fins.2019.4.04

JEL Classification: G32, G34

\begin{abstract}
The aim of the paper is to determine if there is any link between goodwill recognised in a business combination and the future performance of the combined company. The authors focused on examining the effects that business combinations had on the profitability of selected companies, performing a statistical analysis of their financial results. The study covered 730 Polish companies participating in a merger process (the acquiring company was examined at the time of the merger and 3 years after the merger date). The research included companies disclosing positive goodwill (99 companies) and not disclosing it (631 companies). The research period covered mergers in the years 2007-2012. The profitability analysis for 3 years after the merger covered the period until 2015. The result of the empirical research shows that the companies which recognised goodwill during the merger process were more profitable in the examined period of time. The study contributes to a wide research area focusing on examining the effects of business combinations on the future efficiency of combined companies.
\end{abstract}

Keywords: mergers and acquisitions, business combinations, goodwill, efficiency, profitability.

\section{Introduction}

It may be assumed that one of results of a business combination (also called mergers and/or acquisitions in the further text), be it a merger or an acquisition, should be the increase in the combined company's efficiency, which in turn should lead to the 
increase in the company's profitably. However, research on these phenomena provides rather mixed results. There is evidence that such a link indeed exists (e.g. Arvanitis and Stucki, 2015). At the same time the evidence to the contrary may also be found (e.g. King, Dalton, Daily, and Covin, 2004). This situation resulted in additional research examining the connections between other factors which may or may not have an effect on business activities of the combined company and its future financial results.

The aim of this paper is to examine if there is any connection between the recognition of goodwill from a business combination and the future profitability of the combined company which recognised it. The authors hypothesise that the recognition of goodwill in the process of a business combination may point to the fact that it will positively affect the profitability of these companies within three years after the business combination has taken place. The research methods involve literature analysis as well as a statistical analysis of the financial data of selected companies. The research sample covers Polish companies.

The paper consists of three parts. In the first of them the authors provided an overview of literature on the subject of merger and acquisitions and further effects they have on the merged companies. The next part is a description of the methodology used in the empirical research. In the third part the results of the empirical research and the conclusions are presented.

\section{Literature review}

Literature on the subject of the connection between mergers and acquisitions (M\&A), and profitability is extensive. However, the results of this research are mixed. Some of them prove the negative link between the post-merger activity of acquirers and their profitability, as it was mentioned by Hitt, King, Krishnan, Makri, Schijven, and Shimizu (2012) and further researched by King et al. (2004) or Jakubik and Zafeiris (2016). A very original approach to the issue was taken by Malmendier, Moretti, and Peters (2018), who focused on examining the issue from the point of companies which did not take part in M\&A (losers), comparing them with similar companies involved into M\&A transactions (winners). Their findings show that despite similar stock returns for the period of three years before the merger, three years after the merger losers outperformed winners.

On the other hand research providing the evidence to the contrary also exists, proving that mergers and acquisition may increase the profitability of the combined company (e.g. Arvanitis and Stucki, 2015; Valouch and Nesleha, 2018; Beverly, Sutejo, and Murhadi, 2019). In some cases making the final conclusion appears more complicated and needs to take into consideration more factors than just profitability. For example Rutkowski (2018) noted that whereas serial acquirers will have a lower return on equity (ROE) and a lower return on total assets (ROA), at the same time 
they increase their assets more quickly and achieve a higher sales growth in comparison to other companies.

In some cases the research results may even be the cause of confusion for their readers as for the same region, different conclusions may be made by different researchers. For example in their research focused on the banking sector, Pahuja and Aggarwal (2016) noted that there was no significant evidence which would point to increase in profitability of the merged company. In another research Gupta and Banerjee (2017) argued on the basis of their research that no improvement in the profitability of acquirers post-merger was made, quite the contrary. The profitability ratios in their selected sample decreased after the mergers. However, both of these results stand in opposition to another research by Aggarwal and Garg (2019), who eventually concluded that there was a positive correlation between mergers and postmerger profitability and liquidity of the acquirer, however, their solvency remained not significantly affected. They also noticed differences in post-merger performance of firms in different sectors.

Such different conclusions made on the basis of merger data from the same country may surprise at first. It should be noted, however, that in each of the research, the size of the sample and the time frame of the analysed mergers differ. As such, the newest research appears the most comprehensive, not only with the sample size, but also with the number of years used for comparison (five vs. the usual three), which definitely affected the final results. It may also suggest that any improvement in the performance of the acquirer should rather be expected in a long term than in shorter one.

Another research trend focuses on connecting the post-merger performance of acquirers with other factors and searching for explanations of such different results when it comes to post-merger performance of the acquirer.

Harrison, Hitt, Hoskisson, and Ireland (1991) explored differences and similarities between merging companies, concluding that traditional distinction between related and unrelated mergers was losing its meaning. The usual approach assumed that to create synergy, similarities among resources in the acquiring and target firms must exist, however this research proved that it was the differences that contributed significantly to the post-merger performance of the companies.

Bouwman, Fuller, and Nain (2007) linked the quality of acquisitions (and future profitability) with the market valuation, proving that depending on when the transaction took place (boom vs. recession), their effects would differ. The announcement returns made in high-valuation markets were usually better than these in the low-valuation markets; however, in the long term this situation would be reversed due to the higher quality of acquisitions undertaken during the periods of lower market valuation.

Another approach focused on the role of accounting rules. Dickinson, Wangerin, and Wild (2016) argued that other research did not take into consideration the effects of the method of accounting for business combination on future profitability of the 
combined company. Moreover, their findings further suggested that the matter of recognition rules was also not fully taken into consideration by investors and analyst while assessing the performance of the merged companies.

Fernández, Triguero, and Alfaro-Cortés (2019) explored the effects of M\&A on profitability and research and development (R\&D) intensity in large European firms. Their research focused on companies considered to be top European R\&D investors and ultimately proved the link between mergers and R\&D intensity and profitability in them, but only in the long term in case of profitability, whereas the effects of mergers on R\&D may be observed in both, long and short term.

Liu, Sono, and Zhang (2019) linked profitability of the combined companies with the quality of the decision about the merger and the profitability of the acquirer itself. According to them, a more profitable company will make a well thought out decision about the transaction, reducing the likelihood of overpaying for the acquiree, which will lead to the acquirer being more profitable in the future. In turn, firms with higher profitability will likely end as more profitable after making acquisitions. A similar conclusion was made by Galavotti (2019), who argued that good performing firms exhibit better post-acquisition returns.

The result of this research is similar in its findings to another research. Bruyland, Lasfer, De Maeseneire, and Song (2019) concluded that high-default-risk acquirers were likely to select bigger, less profitable targets, pursue transactions during recessions and may be prone to overpaying the transactions. In long term this strategy would negatively affect their profitability.

Having analysed what factors have been taken into consideration while investigating the effects that M\&A may have on the combined companies, the authors started to wonder if goodwill recognised on the merger and later presented in the financial statement of the combined company may be any indication of the future profitability of the combined company. As this particular item of assets represents some future economic benefits arising from other assets which were acquired in a business combination, it may be reasonably assumed that its existence does not only point to some added values that have already been created in the company being acquired. It should also contribute to improving the effects of business activities of the acquirer through the synergy effect.

This led the authors to formulate the following hypothesis: the recognition of goodwill in the process of a business combination may positively affect the profitability of the combined companies within three years after the business combination took place.

Following this line of thoughts, the authors deepened their literary research, which led them to discover that the matter of goodwill in business combinations had already been investigated to a certain extent. There are studies trying to link goodwill presented in the financial statements of the merged companies with higher profitability they achieve in comparison to other companies and proving the positive correlation between the two (Xiao and Liu, 2016; Li and Sun, 2016; Satt and Chetioui, 2017). However, no such research has been done in Poland. 


\section{Methodology and data selection}

The study covered 730 Polish companies participating in the merger process (the acquiring company was examined at the time of the merger and 3 years after the merger date). The research included companies disclosing positive goodwill (99 companies) and companies not disclosing goodwill (631 companies). The moment of merger in this research means the first financial statement prepared by the merged companies. The moment "1 year after merger" means next year after the first combined financial statements. The moment " 3 years after merger" means balance sheet date 3 years after the first combined report.

The research period covered mergers in the years 2007-2012. The profitability analysis for 3 years after the merger covered the period until 2015.

The selection of the research sample is as follows:

1. Companies met the criterion of having financial statements up to 3 years after the merger.

2. If, in the year preceding the merger, the goodwill recognized was less than in the period after the merger, then it is assumed that the company disclosed positive goodwill as a result of the merger.

3. The merger excludes cases where simultaneous increases in positive and negative goodwill were disclosed. This situation may indicate that the acquiring company may have carried out two business combinations with other businesses.

In order to check whether the disclosed positive goodwill affects the financial results, the following variables were adopted:

1. Good_will - independent variable $(1-$ discloses goodwill, 0 - does not disclose it).

2. diffROA01 - dependent variable $(1$ - positive ROA change between the moment of merger and 1 year after the merger, 0 - negative change).

3. diffROA03 - dependent variable ( 1 - positive change in ROA between the moment of connection and the 3 rd year after connection, 0 - negative change).

4. ROA - return on assets is calculated at the level of result on profit or loss on basic operating activities. In this way, the impact of depreciation of the goodwill is reduced, which is recognized in other operating costs or other operating revenues.

5 . ROA 1 - return on assets at the balance sheet date 1 year after merger date.

6. ROA3 - return on assets at the balance sheet date 3 years after merger date.

\section{Research results}

1. Descriptive statistics ROA for the moment of merger and 3 years after the merger (table 1).

On the basis of table 1 it can be concluded that the medians were similar, at 0.025 and 0.023 . 
Table 1. Descriptive statistics for ROA

\begin{tabular}{|l|c|c|c|c|c|c|}
\hline \multirow{2}{*}{ Variable } & \multicolumn{7}{|c|}{ All Groups Descriptive Statistics } \\
\cline { 2 - 7 } & Valid N & Mean & Median & Minimum & Maximum & Std.Dev. \\
\hline ROA & 730 & 0.0380 & 0.0254 & -2.0471 & 1.2277 & 0.2068 \\
\hline ROA3 & 730 & 0.0295 & 0.0234 & -2.8341 & 0.9034 & 0.2335 \\
\hline
\end{tabular}

Source: own work.

2. Descriptive statistics ROA in the group of companies disclosing positive goodwill or not disclosing a positive goodwill at the moment of merger and for 3 years after the merger (table 2).

Table 2. Descriptive statistics for ROA - positive goodwill, no goodwill

\begin{tabular}{|l|c|c|c|c|c|c|c|}
\hline \multirow{3}{*}{ Variable } & \multicolumn{7}{|c|}{$\begin{array}{c}\text { Aggregate Results } \\
\text { Descriptive Statistics }\end{array}$} \\
\cline { 2 - 8 } & Good_will & Valid N & Mean & Median & Minimum & Maximum & Std.Dev. \\
\hline ROA & 1 & 99 & 0.0110 & 0.0172 & -2.0471 & 0.4339 & 0.2405 \\
\hline ROA3 & 1 & 99 & 0.0195 & 0.0168 & -2.5848 & 0.9034 & 0.3182 \\
\hline ROA & 0 & 631 & 0.0422 & 0.0267 & -1.7835 & 1.2277 & 0.2008 \\
\hline ROA3 & 0 & 631 & 0.0311 & 0.0241 & -2.8341 & 0.8722 & 0.2175 \\
\hline
\end{tabular}

Source: own work.

3. Medians of ROA in companies disclosing goodwill were similar at 0.017 . Medians of ROA in companies not disclosing goodwill were similar at 0.026 and 0.024 .

Equality test ROA on the moment of merger in a group of companies disclosing the company's goodwill and not revealing the company's goodwill. The nonparametric Mann-Whitney test was used (table 3).

Table 3. Mann-Whitney equality test for ROA medians

\begin{tabular}{|c|c|c|c|c|c|c|c|c|c|}
\hline \multirow{2}{*}{ Variable } & \multicolumn{9}{|c|}{$\begin{array}{c}\text { Mann-Whitney U Test } \\
\text { By variable Good_will } \\
\text { Marked tests are significant at } p<, 05000\end{array}$} \\
\hline & $\begin{array}{l}\text { Rank Sum } \\
\text { (Group 1) }\end{array}$ & $\begin{array}{l}\text { Rank Sum } \\
\text { (Group 2) }\end{array}$ & U & Z & p-value & $\begin{array}{c}\mathrm{Z} \\
\text { (adjusted) }\end{array}$ & $\mathrm{p}$-value & $\begin{array}{c}\text { Valid N } \\
\text { (Group } \\
1 \text { ) }\end{array}$ & $\begin{array}{c}\text { Valid N } \\
\text { (Group } \\
\text { 2) }\end{array}$ \\
\hline ROA & 33270.00 & 233545.0 & 28320.00 & -1.4938 & 0.1352 & -1.4938 & 0.1352 & 99 & 631 \\
\hline ROA1 & 35103.00 & 231712.0 & 30153.00 & -0.5541 & 0.5795 & -0.5541 & 0.5795 & 99 & 631 \\
\hline ROA3 & 34344.00 & 232471.0 & 29394.00 & -0.9432 & 0.3456 & -0.9432 & 0.3456 & 99 & 631 \\
\hline
\end{tabular}

Source: own work. 
On the basis of the median equality test, it can be concluded that the medians in groups (companies revealing "positive" goodwill and companies not disclosing goodwill) for the period of merger, one year after the merger, and 3 years after the merger did not differ significantly (at the level of $\alpha=0.05$ ). Hypothesis 0 : medians in groups are equal.

4. The next stage of the study includes checking changes in the profitability of assets in the years $0-1$ and in the years $0-3$.

Based on the data collected in the group of companies revealing the positive goodwill, 55 units out of 99 companies $(55 \%)$ revealed a positive change in profitability in the period of 1 year after the merger. Based on the collected data, in the group of companies disclosing the positive goodwill, 45 units out of 99 companies $(45 \%)$ revealed a positive change in profitability over a 3-year period. Based on the collected data, in the group of companies not disclosing the goodwill, 265 units out of 631 companies $(42 \%)$ revealed a positive change in profitability in the period of 1 year after the merger. Based on the collected data, in the group of companies not disclosing the company's value, 220 units out of 631 companies $(35 \%)$ revealed a positive change in profitability over a 3 -year period.

5. The last stage of verification of the research hypothesis includes the preparation of logit models.

The logit models are simple to understand and they are considered the best practice in social sciences (Osborne, 2015). The variable that determines the disclosure of goodwill (Good_will) will be an independent variable. The variable will determine the change (sign) of the operating margin of assets at the moment: 1 year after the merger and 3 years after the merger.

Table 4. Parameters estimates of ROA change between merger date and 1 year after merger date

\begin{tabular}{|l|c|c|c|c|c|c|c|c|}
\hline \multirow{3}{*}{ Effect } & \multicolumn{7}{|c|}{$\begin{array}{c}\text { sign_01-Parameter Estimates } \\
\text { Distribution: BINOMIAL, Link function: LOGIT } \\
\text { Modelled probability that sign_01 =0 }\end{array}$} \\
\cline { 2 - 10 } & $\begin{array}{c}\text { Level of } \\
\text { (Effect) }\end{array}$ & Column & Estimate & $\begin{array}{c}\text { Standard } \\
\text { (Error) }\end{array}$ & $\begin{array}{c}\text { Wald } \\
\text { (Stat.) }\end{array}$ & $\begin{array}{c}\text { Lower CL } \\
(95.0 \%)\end{array}$ & $\begin{array}{c}\text { Upper CL } \\
(95.0 \%)\end{array}$ & $\mathrm{p}$ \\
\hline Intercept & & 1 & 0.0499 & 0.1089 & 0.2099 & -0.1635 & 0.2633 & 0.6469 \\
\hline Good_will & 0 & 2 & 0.2730 & 0.1089 & 6.2885 & 0.0596 & 0.4864 & 0.0122 \\
\hline Scale & & & 1.0000 & 0.0000 & & 1.0000 & 1.0000 & \\
\hline
\end{tabular}

Source: own work.

Based on the regression parameters, it can be concluded that the Good_will variable is a statistically significant variable (table 4).

The odds ratio (table 5) for the Good_will variable 1,7264 (higher than 1) means that the disclosure of goodwill increases the likelihood of a positive change in the profitability of assets in years (0-1). The interpretation is as follows: disclosure of 
Table 5. Odds ratio ROA change between merger date and 1 year after merger date

\begin{tabular}{|c|c|c|c|c|c|c|}
\hline \multirow{3}{*}{ Effect } & \multicolumn{7}{|c|}{$\begin{array}{c}\text { sign_01 - Odds Ratios } \\
\text { Distribution: BINOMIAL, Link function: LOGIT } \\
\text { Modelled probability that sign_01 = 0 }\end{array}$} \\
\cline { 2 - 7 } & $\begin{array}{c}\text { Level } \\
\text { of (Effect) }\end{array}$ & Column & $\begin{array}{c}\text { Odds } \\
\text { (Ratio) }\end{array}$ & $\begin{array}{c}\text { Lower CL } \\
(95.0 \%)\end{array}$ & $\begin{array}{c}\text { Upper CL } \\
(95.0 \%)\end{array}$ & $\mathrm{p}$ \\
\hline Intercept & & 1 & & & & 2.6454 \\
\hline Good_will & 0 & 2 & 1.7264 & 1.1267 & 0.0122 \\
\hline
\end{tabular}

Source: own work.

positive goodwill increases the chance of a positive change in ROA in 1 year after a merger by $72.6 \%$.

6 . The last stage of verification of the research hypothesis includes the preparation of logit models.

The variable that determines the disclosure of goodwill (Good_will) will be an independent variable. The variable will determine the change (sign) of the operating margin of assets at the moment: 3 years after the merger (table 6).

Based on the regression parameters, it can be concluded that the Good_will variable is a statistically significant variable.

Table 6. Parameters estimates of ROA change between merger date and 3 years after merger date

\begin{tabular}{|l|c|c|c|c|c|c|c|c|}
\hline \multirow{3}{*}{ Effect } & \multicolumn{7}{|c|}{$\begin{array}{c}\text { Sign 03 - Parameter Estimates } \\
\text { Distribution: BINOMIAL, Link function: LOGIT } \\
\text { Modelled probability that sign_03 =0 }\end{array}$} \\
\cline { 2 - 10 } & $\begin{array}{c}\text { Level } \\
\text { of (Effect) }\end{array}$ & Column & Estimate & $\begin{array}{c}\text { Standard } \\
\text { (Error) }\end{array}$ & $\begin{array}{c}\text { Wald } \\
\text { (Stat.) }\end{array}$ & $\begin{array}{c}\text { Lower CL } \\
(95.0 \%)\end{array}$ & $\begin{array}{c}\text { Upper CL } \\
(95.0 \%)\end{array}$ & p \\
\hline Intercept & & 1 & 0.4036 & 0.1092 & 13.6572 & 0.1896 & 0.6177 & 0.0002 \\
\hline Good_will & 0 & 2 & 0.2213 & 0.1092 & 4.1060 & 0.0072 & 0.4354 & 0.0427 \\
\hline Scale & & & 1.0000 & 0.0000 & & 1.0000 & 1.0000 & \\
\hline
\end{tabular}

Source: own work.

Table 7. Odds ratio ROA change between merger date and 3 years after merger date

\begin{tabular}{|l|c|c|c|c|c|c|}
\hline \multirow{3}{*}{ Effect } & \multicolumn{7}{|c|}{$\begin{array}{c}\text { Sign_03-Odds Ratios } \\
\text { Distribution: BINOMIAL, Link function: LOGIT } \\
\text { Modelled probability that sign_03 = }\end{array}$} \\
\cline { 2 - 7 } & $\begin{array}{c}\text { Level } \\
\text { of (Effect) }\end{array}$ & Column & Odds (Ratio) & $\begin{array}{c}\text { Lower CL } \\
(95.0 \%)\end{array}$ & $\begin{array}{c}\text { Upper CL } \\
(95.0 \%)\end{array}$ & $\mathrm{p}$ \\
\hline Intercept & & 1 & & & & \\
\hline Good_will & 0 & 2 & 1.5568 & 1.0146 & 2.3888 & 0.0427 \\
\hline
\end{tabular}

Source: own work. 
The odds ratio (table 7) for the Good_will variable 1.5568 (greater than 1) means that the disclosure of goodwill increases the probability of a positive change in the profitability of assets in the years (0-3). The interpretation is as follows: disclosure of positive goodwill increases the chance of a positive change in ROA in 3 years (compared to the merger of companies) after a combination of $55.7 \%$.

\section{Conclusions}

The aim of this paper is to find out if there is any influence of disclosing positive goodwill, as a result of the merger process, on companies' profitability. Based on the research results on Polish companies merging in the period 2007-2012, we proved that companies disclosing positive goodwill as a result of the merger achieved increases in return on assets in the following periods: 1 year after a merger and 3 years after a merger. Therefore, the authors confirmed the stated hypothesis that the recognition of goodwill in the process of a business combination may positively affect the profitability of the combined companies within three years after the business combination took place.

\section{References}

Aggarwal, P., and Garg, S. (2019). Impact of mergers and acquisitions on accounting-based performance of acquiring firms in India. Global Business Review DOI: 10.1177/0972150919852009

Arvanitis, S., and Stucki, T. (2015). Do mergers and acquisitions among small and medium-sized enterprises affect the performance of acquiring firms? International Small Business Journal, 33(7), 752-773. DOI: $10.1177 / 0266242614522280$

Beverly, C., Sutejo, B. S., and Murhadi, W. R. (2019, March). Company performance before and after a merger (16th International Symposium on Management (INSYMA 2019)). Atlantis Press. DOI: 10.2991/insyma-19.2019.8

Bouwman, C. H., Fuller, K., and Nain, A. S. (2007). Market valuation and acquisition quality: Empirical evidence. The Review of Financial Studies, 22(2), 633-679. DOI: 10.1093/rfs/hhm073

Bruyland, E., Lasfer, M., De Maeseneire, W., and Song, W. (2019). The performance of acquisitions by high default risk bidders. Journal of Banking \& Finance, (101), 37-58. DOI: 10.1016/j.jbankfin.2019.01.019

Dickinson, V., Wangerin, D. D., and Wild, J. J. (2016). Accounting rules and post-acquisition profitability in business combinations. Accounting Horizons: December 2016, 30(4), 427-447. DOI: 10.2308/ acch-51504

Fernández, S., Triguero, Á., and Alfaro-Cortés, E. (2019). M\&A effects on innovation and profitability in large European firms. Management Decision, 57(1), 100-114. DOI: 10.1108/MD-08-2017-0730

Galavotti, I. (2019). Firm-level recent profitability and acquisition performance: Exploring competing theoretical perspectives. Eurasian Business Review, 9(3), 319-345.

Gupta, B., and Banerjee, P. (2017). Impact of merger and acquisitions on financial performance: Evidence from selected companies in India. In Conference Proceedings of IMS Business School Doctoral Colloquium (pp. 14-19).

Harrison, J. S., Hitt, M. A., Hoskisson, R. E., and Ireland, R. D. (1991). Synergies and post-acquisition performance: Differences versus similarities in resource allocations. Journal of Management, 17(1), 173-190. DOI: 0.1177/014920639101700111 
Hitt, M. A., King, D., Krishnan, H., Makri, M., Schijven, M., and Shimizu, K. (2012). Creating value through mergers and acquisitions. In D. Faulkner, S. Teerikangas, \& R. J. Joseph (Eds.), The hand-book of mergers and acquisitions (pp. 71-113). Oxford: Oxford University Press. DOI: 10.1093/ acprof:oso/9780199601462.001.0001

Jakubik, P., and Zafeiris, D. (2016). Impact of mergers and acquisitions on European insurers: Evidence from equity markets (IES Working Paper No. 12).

King, D. R., Dalton, D. R., Daily, C. M., and Covin, J. G. (2004). Meta-analyses of post-acquisition performance: Indications of unidentified moderators. Strategic Management Journal, 25(2), 187-200. DOI: $10.1002 / \mathrm{smj} .371$

Li, Z., and Sun, H. (2016). The Correlation Analysis of Financial Performance and Goodwill of the Listed Companies. In G. Lee (Ed.), Advances in Education Research (vol. 93, pp. 185-191).

Liu, Q., Sono, H., and Zhang, W. (2019). Management quality and acquisition performance: New evidence based on firm profitability. Journal of Corporate Accounting \& Finance, 30(3), 44-63. DOI: $10.1002 /$ jcaf.22388

Malmendier, U., Moretti, E., and Peters, F. S. (2018). Winning by losing: Evidence on the long-run effects of mergers. The Review of Financial Studies, 31(8), 3212-3264. DOI: 10.1093/rfs/hhy009

Osborne, J. W. (2015). Curvilinear Effects in Logistic Regression. Best Practices in Logistic Regression. Thousand Oaks, CA: Sage Publications.

Pahuja, A., and Aggarwal, S. (2016). Impact of mergers and acquisitions on financial performance: Evidence from Indian banking industry. International Journal of Applied Finance and Accounting (IJAFA), 1(2), 1-18. Retrieved from https://ssrn.com/abstract=2857554

Rutkowski A. (2018). Profitability of Serial Acquirers on the Polish Capital Market. In: K. Jajuga, H. Locarek-Junge, L. Orlowski (Eds.), Contemporary Trends and Challenges in Finance (pp. 211-218). Springer Proceedings in Business and Economics. Cham: Springer. DOI: 10.1007/ 978-3-319-76228-9 20

Satt, H., and Chetioui, Y. (2017). Does goodwill improve firm performance? Evidence from the Mena region. Risk Governance \& Control: Financial Markets \& Institutions, 7(2), 108-115. DOI: 10.22495/ rgcv7i2art10

Valouch, P., and Nesleha, J. (2018). Impact of Mergers on the Company Performance. European Financial Systems, 788.

Xiao, L., and Liu, Y. (2016). The impact of the merger goodwill on the profitability of the enterprise. Journal of Interdisciplinary Mathematics, 19(4), 749-758. DOI: 10.1080/09720502.2016.1179492

\section{CZY WARTOŚĆ FIRMY UJAWNIONA PO POŁĄCZENIU SPÓŁEK WSKAZUJE NA PRZYSZLĄ RENTOWNOŚĆ POŁĄCZONEJ JEDNOSTKI?}

Streszczenie: Celem artykuły było określenie, czy istnieje powiązanie pomiędzy wartością firmy ujawnioną w wyniku połączenia spółek i przyszłymi wynikami osiąganymi przez jednostkę połączoną. Autorzy skoncentrowali uwagę na zbadaniu wpływu połączenia spółek na rentowność wybranych spółek i przeprowadzili statyczną analizę wyników finansowych przez nie osiagniętych. Badanie objęło 730 polskich spółek, które uczestniczyły w połączeniu. Jednostki przejmujące były badane w roku, w którym nastąpiło połączenie, oraz trzy lata po dniu połączenia. Wśród badanych spółek znalazły się te, które ujawniły wartość firmy (99 spółek), oraz te, które wartości firmy nie ujawniły (631 spółek). Badanie obejmowało połączenia przeprowadzone w latach 2007-2012. Analiza rentowności za okres trzech lat po połączeniu obejmowała okres do 2015 roku. Wyniki badania empirycznego wskazują, że spółki, które ujwaniły wartość firmy z połączenia, były bardziej rentowne w analizowanym okresie. Artykuł stanowi wkład do badań koncentrujących się na wpływie połączeń spółek na przyłą efektywność działania spółek połączonych.

Słowa kluczowe: fuzje i przejęcia, połączenia spółek, wartość firmy, efektywność działania, zyskowność. 